OPEN ACCESS

Edited by:

Michael Sweet,

University of Derby, United Kingdom

Reviewed by:

Julie L. Meyer,

University of Florida, United States

Angela Poole,

Berry College, United States

${ }^{*}$ Correspondence:

David S. Gilliam

gilliam@nova.edu

Specialty section:

This article was submitted to

Coral Reef Research,

a section of the journal

Frontiers in Marine Science

Received: 31 May 2018

Accepted: 23 August 2018

Published: 13 September 2018

Citation:

Walton CJ, Hayes NK and Gilliam DS

(2018) Impacts of a Regional, Multi-Year, Multi-Species Coral Disease Outbreak in Southeast Florida. Front. Mar. Sci. 5:323. doi: 10.3389/fmars.2018.00323

\section{Impacts of a Regional, Multi-Year, Multi-Species Coral Disease Outbreak in Southeast Florida}

\author{
Charles J. Walton, Nicole K. Hayes and David S. Gilliam* \\ Halmos College of Natural Sciences and Oceanography, Nova Southeastern University, Dania Beach, FL, United States
}

Globally coral reefs have been declining at alarming rates as a result of anthropogenic stressors, leading to increased frequency and severity of widespread bleaching and disease events. These events are often associated with increased water temperatures due to climate change as well as regional and local stress from nutrient enrichment through runoff and sedimentation from coastal development. In late 2014, a white syndrome disease outbreak was reported off the coast of southeast Florida and was subsequently documented spreading throughout the region. This study examined the regional impacts of the disease event on the southeast Florida stony coral population utilizing stony coral demographic data from the Southeast Florida Coral Reef Evaluation and Monitoring Project (SECREMP). SECREMP is a long-term monitoring project examining 22 sites distributed from Miami-Dade County north to Martin County, Florida. The results revealed significant region-wide declines in stony coral diversity, density, and live tissue area corresponding with increased disease prevalence, which reached its maximum for the study period in 2016. Regional declines in coral density approached $30 \%$ loss and live tissue was upward of $60 \%$ as a result of the disease outbreak. Additionally, multiple species were severely impacted, especially the reef building, complexity-contributing species Montastraea cavernosa, Meandrina meandrites, and Siderastrea siderea. The disease outbreak resulted in acute mortality and altered the ecosystem function to a point such that recovery is uncertain. This multiyear, regionwide disease outbreak has been indiscriminate relative to coral species impacted and was arguably the most devastating disturbance event documented on the Southeast Florida Reef Tract.

Keywords: white syndrome, Florida Reef Tract, coral mortality, density, diversity, cover, long-term monitoring

\section{INTRODUCTION}

Disease outbreaks on coral reefs are emerging as significant causes of coral mortality altering ecosystem function and are predicted to become more frequent and severe globally (Harvell et al., 2002; Maynard et al., 2015). Evidence continues to build coupling increased water temperatures with increased coral bleaching and disease prevalence (Croquer and Weil, 2009; Miller et al., 2009; Ruiz-Moreno et al., 2012; Randall and van Woesik, 2015). In addition to thermal stress, other anthropogenically influenced stressors linked to increased coral disease prevalence and mortality include reduced water quality (Bruno et al., 2003) and clarity (van Woesik and McCaffrey, 2017), 
nutrient enrichment (Vega Thurber et al., 2013), dredging associated sedimentation (Pollock et al., 2014; Miller et al., 2016), and plastic pollution (Lamb et al., 2018). As anthropogenic related stressors continue to drive disturbance events such as disease outbreaks, it is imperative to document how these events are affecting coral reef ecosystems.

Coral disease, especially in the Caribbean, was once typically described as more prevalent during summer months affecting less than $5 \%$ of the population and only a few species (Rutzler et al., 1983; Edmunds, 1991; Bruno et al., 2007; Weil and Croquer, 2009; Muller and van Woesik, 2012; Ruiz-Moreno et al., 2012). These typical conditions have now changed. The pathogens, vectors, or other causative agents of most coral diseases remain unknown. Sufficient information on background disease prevalence in coral populations or what factors contribute to prevalence levels increasing to a height such that major coral community changing disease outbreaks occur is not known. It is becoming increasingly important to understand the interactions between climate-related stress and local environmental factors that are likely to contribute to increased disease prevalence, whether through changes in pathogen abundance or virulence, or coral susceptibility to disease.

In this study, we use a 5-year data set collected as part of a long-term monitoring project to examine the impacts of a multi-year, widespread disease outbreak on stony coral populations in the northern portion of the Florida Reef Tract (FRT). The FRT is the third largest barrier reef system in the world extending approximately $577 \mathrm{~km}$ north from the Dry Tortugas. The northern extension of the FRT, the Southeast Florida Reef Tract (SEFRT), runs parallel to the heavily developed and densely populated mainland coast of southeast Florida, which includes Miami-Dade, Broward, Palm Beach, and Martin counties. Southeast Florida is home to more than six million residents and visited by millions of tourists each year. Existing within $3 \mathrm{~km}$ of this highly urbanized area, the SEFRT ecosystem is greatly influenced by commercial and recreational fishing and diving, major shipping port activities including dredging, wastewater and sewer outfalls, canal discharges, ship groundings, and other marine construction activities. The cumulative impact of these local stressors on the SEFRT is likely even more damaging through the interaction with increasingly frequent and severe thermal stress associated with global climate change.

Reports of numerous diseased corals in the southern portion (Miami-Dade County) of the SEFRT began in the fall of 2014 and by fall 2015 reports increased, identifying an apparent widespread disease outbreak affecting numerous species in the south and central portions of the SEFRT ${ }^{1}$ (Precht et al., 2016). Increased ocean warming (Manzello, 2015) followed by coral bleaching were reported in late summer and fall 2014 in the FRT and continued through 2015 (Eakin et al., 2016; van Woesik and McCaffrey, 2017). With reports continuing through 2016, this regional disease outbreak appeared to be more severe, widespread, and prolonged compared to previous disease outbreaks documented along the FRT.

\footnotetext{
${ }^{1}$ https://floridadep.gov/fco/coral/content/florida-reef-tract-coral-diseaseoutbreak
}

Historically, the Caribbean has been considered a "hotspot" for coral disease and the FRT has not been an exception. Disease outbreaks affecting multiple coral species were reported in the FRT in the 1970s (Dustan, 1977) and 1990s (Richardson et al., 1998a,b). The visual signs and tissue loss patterns affecting the corals in these events led to the disease being termed white plague (Dustan and Halas, 1987; Richardson et al., 1998a,b). In the Caribbean, white plague is now considered to be one of the most serious of the coral diseases (Croquer et al., 2003; Weil, 2004; Richardson and Voss, 2005; Miller et al., 2009). In addition to the previous observations of white plague along the FRT, black band disease (Carlton and Richardson, 1995; Kuta and Richardson, 1996) and Acroporid only affecting diseases, whiteband (Gladfelter, 1982; Aronson and Precht, 2001), white-pox (Sutherland and Ritchie, 2004), and rapid tissue loss (Williams and Miller, 2005) have also been documented (Gilliam et al., 2017). The disease presentation in the current study commonly consisted of tissue loss from disease lesions or boundaries of denuded skeleton adjacent to apparently healthy tissue. As the outbreak has been studied and discussed among research partners multiple names have been used including, white plague, white blotch, and white-plague like. Given the current unknown information regarding the outbreak, the accepted identification of the white plague pathogen and that this study did not attempt to identify the pathogen, the disease is referred to as white syndrome (WS). This is supported by ongoing work of others trying to identify the pathogen ${ }^{2,3}$ (Walczak, personal communication, 2018). Additionally, the term WS is commonly used in the Pacific for diseases with similar presentation and unknown etiologies (Pollock et al., 2011, 2017).

Here, we utilized Southeast Florida Coral Reef Evaluation and Monitoring Project (SECREMP) data collected between 2012 and 2016 to examine disease outbreak impacts on the stony coral community. SECREMP is a long-term monitoring project that includes 22 sites distributed along the SEFRT from MiamiDade County north to Martin County (Gilliam et al., 2017). The specific objectives of this study were to determine the temporal and spatial extent of the outbreak and to quantify region-wide and species specific impacts to the stony coral community. The data presented here clearly show significant declines in coral diversity, density, and live tissue area (LTA) associated with an unprecedented disease outbreak. Additionally, capturing these declines demonstrates the value of continued region-wide, long-term monitoring, and the importance of these projects for determining the success of management actions that will be required in response to this disease outbreak.

\section{MATERIALS AND METHODS}

\section{Coral Monitoring Surveys}

To evaluate the impacts of the major coral disease outbreak offshore southeast Florida, this study utilized stony coral

\footnotetext{
${ }^{2}$ https://futurism.com/white-syndrome-coral-reef-florida/

${ }^{3}$ https://www.nrdc.org/stories/scientists-are-battling-mysterious-pathogendestroying-coral-reefs-floridas-coast
} 
demographic data from SECREMP. SECREMP was established as a long-term monitoring project in 2003 to provide resource managers annual status updates on the SEFRT (Gilliam et al., 2017). In 2012, SECREMP began collecting detailed stony coral demographic data at 16 previously established permanent monitoring sites and in 2013 six additional sites were added. The 22 sites were distributed north from Miami-Dade County to Martin County (Figure 1 and Table 1) with multiple reef habitats within each county (Walker, 2012) represented. Throughout the project, sites have been defined by the county followed by a site number $(\mathrm{MC}=$ Martin County, $\mathrm{BC}=$ Broward County, $\mathrm{PB}=$ Palm Beach County, and $\mathrm{DC}=$ Dade County). Each site consists of four stations, $1 \mathrm{~m} \times 22 \mathrm{~m}$, demarcated by stainless steel stakes permanently placed in the substrate. Annual monitoring surveys at all sites occurred in summer months (May-September) from 2012 to 2016. Using SCUBA, divers conducted $1 \mathrm{~m} \times 22 \mathrm{~m}$ belt transects guided by measuring tapes deployed between the permanent stakes. Within each transect all stony corals $\geq 4 \mathrm{~cm}$ diameter were identified to species and colony maximum diameter and height, perpendicular to the plane of growth, were measured. Colonies were visually assessed for signs of disease, bleaching, and other conditions (i.e., predation, damselfish gardens, boring sponges, etc.). For the current study, diseases were classified as non-white syndrome or WS based on disease presentation and the unknown etiology. Non-white syndrome included black band disease, yellow band disease, white band disease (Acroporids only), and dark spot disease. Bleached colonies were differentiated from partially bleached colonies in the field, but data presented in this study combined bleached and partially bleached colonies. Percent colony tissue mortality was documented and estimated as either recent or old mortality. Recent mortality was defined as tissue loss areas having clearly distinguishable corallite structure and minimal overgrowth by algae or other fouling organisms. Any areas of colony mortality not meeting these criteria were considered old.

In addition to the coral surveys, SECREMP has been collecting benthic temperature data at all sites since 2007. Throughout the course of the project, three models of temperature loggers were utilized, StowAway TidbiT ${ }^{\mathrm{TM}}$, Hobo Pendant Temperature Data Logger, and Hobo Water Temp Pro v2 (Onset). Two loggers were deployed at each site with a sampling interval of every $2 \mathrm{~h}$ and were exchanged annually during the monitoring events. Data from one logger per site was used for analysis unless there were gaps in the data in which case data from the second logger was used to fill gaps.

\section{Statistical Analysis}

Temporal trends in regional monthly minimum, maximum, and mean temperatures were examined using a linear regression model in $\mathrm{R}$ (version 3.3.3) ( $\mathrm{R}$ Core Team, 2017). Regional values were calculated using data from all sites and subregional values were calculated using the sites within each respective county.

To examine the extent of the disease outbreak, differences in bleaching and disease prevalence, coral community diversity [species richness $(\mathrm{S})$, Shannon index $\left(\mathrm{H}^{\prime}\right)$, and Inverse Simpson's index (D)], coral density, and coral LTA were analyzed at the regional level. As coral diseases often cause colony partial mortality, LTA is a useful metric because it takes partial mortality into account and is therefore better able to detect changes in the community whereas diversity and density require full colony mortality for changes to be detected. Coral colony surface areas were calculated using the following modified version of the Knud Thomsen approximation ${ }^{4}$ for the surface area of an ellipsoid (Klamkin, 1971, 1976):

$$
S A=2 \pi\left(\frac{\mathrm{a}^{\mathrm{p}}\left(\frac{1}{2} \mathrm{~b}\right)^{\mathrm{p}}+\mathrm{a}^{\mathrm{p}}\left(\frac{1}{2} \mathrm{~b}\right)^{\mathrm{p}}+\left(\frac{1}{2} \mathrm{~b}\right)^{\mathrm{p}}\left(\frac{1}{2} \mathrm{~b}\right)^{\mathrm{p}}}{3}\right)^{\frac{1}{\mathrm{p}}}
$$

The original equation was multiplied by $1 / 2$ to estimate the surface area of a coral as the equivalent of the top half of an ellipsoid. In the equation, $\mathrm{a}=$ maximum colony height, $\mathrm{b}=$ maximum colony diameter, and $p=1.6075$, a constant yielding a relative error of at most $\pm 1.061 \%$, determined by Knud Thomsen based on Klamkin's (1971) work. Following the calculation of the surface area, the resulting value and the colony mortality were used to calculate LTA via the following formula:

$$
\mathrm{LTA}=\mathrm{SA}\left(1-\left(\frac{\% \text { old Mortality }+\% \text { Recent Mortality }}{100}\right)\right)
$$

Disease prevalence, species diversity, colony density, and colony LTA were also analyzed at the site level to detect any localized effects of the disease outbreak. Regional and site level differences were analyzed using linear mixed-effect models in the nlme package (Pinheiro et al., 2017) in R. For these models disease prevalence, diversity, density, or LTA were used as the response variables with year as the fixed effect. For the regional models, station was nested within site as a random effect and for site models station was used as a random effect.

To investigate species-specific effects of the disease outbreak disease prevalence, density, and LTA were examined for each coral species documented throughout the 5 years of monitoring. Species-level disease prevalence was tested for trends over time using the Mann-Kendall trend test in the Kendall package (McLeod, 2011) in R. Linear mixed-effects models were used with species density or LTA as the response variable and year as the fixed effect and a random effect for station nested within site.

For all models, if significant effects were found a Tukey's post hoc analysis was performed using the glht() (general linear hypothesis) function in the multcomp package (Hothorn et al., 2008). Additionally, all figures were generated using the ggplot2 package (Wickham, 2009) in $\mathrm{R}$ and all data are presented as mean \pm standard error (SE) unless noted otherwise.

It should be noted that prior to 2013 SECREMP grouped Orbicella (formerly known as Montastraea) annularis, Orbicella faveolata, and Orbicella franksii as the Orbicella annularis complex and they are therefore grouped for this study. Additionally, Agaricia spp. are grouped as a result of highly variable inter-observer identifications of these species.

\footnotetext{
${ }^{4}$ http://www.numericana.com/answer/ellipsoid.htm
} 


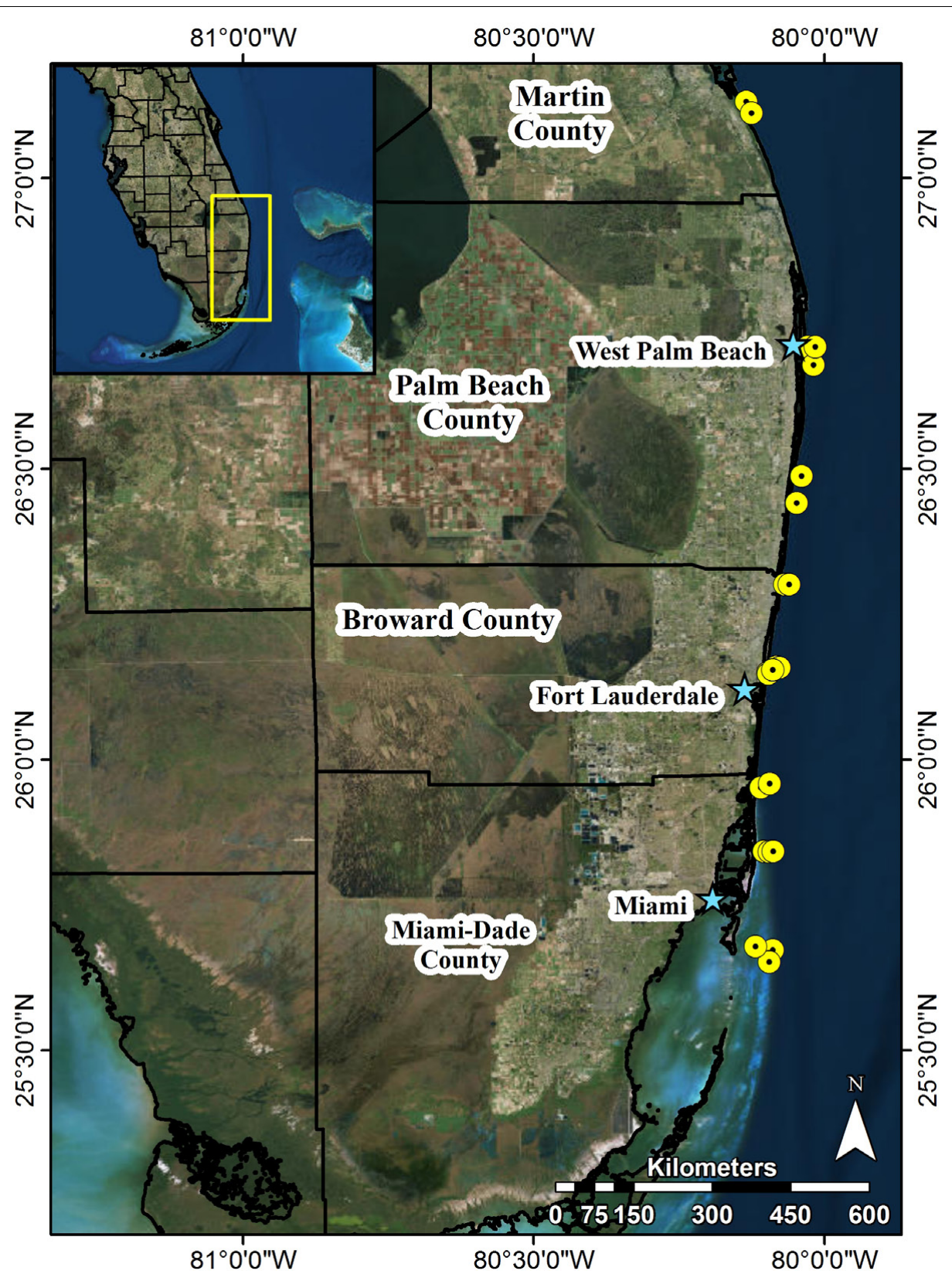

FIGURE 1 | Map of southeast Florida and locations of 22 permanent SECREMP monitoring sites. Each yellow point represents sites, stars name major metropolitan areas, and black outlines represent county boundaries. Site names and descriptive data are included in Table 1.

Additionally, species-level differences are for these complexes not individual species.

\section{RESULTS}

\section{Increased Thermal Stress and Coral Bleaching and Disease}

Benthic temperatures at the SECREMP sites exhibited continued increases from 2007 to 2016, suggesting increased thermal stress throughout the southeast Florida region, which is in agreement with sea surface temperature reports from southeast Florida as well as the Florida Keys (Manzello, 2015; NOAA Coral Reef Watch, 2016). In years with corresponding stony coral demographic data (2012-2016), 2015 was the warmest year documented by SECREMP (Figure 2), based on annual means, and had the most days with maximum temperatures exceeding a documented bleaching threshold of $30.5^{\circ} \mathrm{C}$ (Manzello et al., 2007), especially in Miami-Dade County (Supplementary Table S1). Regionally, increasing trends were observed for monthly maximum, minimum, and mean temperatures, although only the monthly minimum trend was 
TABLE 1 | SECREMP monitoring site characteristics and locations.

\begin{tabular}{llccc}
\hline Site Name & Reef Type & Depth (m) & Latitude (N) & Longitude (W) \\
\hline MC1 & NRC & 4.6 & $27^{\circ} 07.900^{\prime}$ & $80^{\circ} 08.042^{\prime}$ \\
MC2 & NRC & 4.6 & $27^{\circ} 06.722^{\prime}$ & $80^{\circ} 07.525^{\prime}$ \\
PB1 & NRC & 7.6 & $26^{\circ} 42.583^{\prime}$ & $80^{\circ} 01.714^{\prime}$ \\
PB2 & Outer & 16.8 & $26^{\circ} 40.710^{\prime}$ & $80^{\circ} 01.095^{\prime}$ \\
PB3 & Outer & 16.8 & $26^{\circ} 42.626^{\prime}$ & $80^{\circ} 00.949^{\prime}$ \\
PB4 & Outer & 16.8 & $26^{\circ} 29.268^{\prime}$ & $80^{\circ} 02.345^{\prime}$ \\
PB5 & Outer & 16.8 & $26^{\circ} 26.504^{\prime}$ & $80^{\circ} 02.854^{\prime}$ \\
BC1 & NRC & 7.6 & $26^{\circ} 08.872^{\prime}$ & $80^{\circ} 05.758^{\prime}$ \\
BC2 & Middle & 12.2 & $26^{\circ} 09.597^{\prime}$ & $80^{\circ} 04.950^{\prime}$ \\
BC3 & Outer & 16.8 & $26^{\circ} 09.518^{\prime}$ & $80^{\circ} 04.641^{\prime}$ \\
BC4* & Inner & 9.1 & $26^{\circ} 08.963^{\prime}$ & $80^{\circ} 05.364^{\prime}$ \\
BC5* & Middle & 13.7 & $26^{\circ} 18.100^{\prime}$ & $80^{\circ} 04.095^{\prime}$ \\
BC6* & Outer & 16.8 & $26^{\circ} 18.067^{\prime}$ & $80^{\circ} 03.634^{\prime}$ \\
BCA & NRC & 7.6 & $26^{\circ} 08.985^{\prime}$ & $80^{\circ} 05.810^{\prime}$ \\
DC1 & Inner & 7.6 & $25^{\circ} 50.530^{\prime}$ & $80^{\circ} 06.242^{\prime}$ \\
DC2 & Middle & 13.7 & $25^{\circ} 50.520^{\prime}$ & $80^{\circ} 05.704^{\prime}$ \\
DC3 & Outer & 16.8 & $25^{\circ} 50.526^{\prime}$ & $80^{\circ} 05.286^{\prime}$ \\
DC4 & Outer & 12.5 & $25^{\circ} 40.357^{\prime}$ & $80^{\circ} 05.301^{\prime}$ \\
DC5 & Inner & 7.3 & $25^{\circ} 39.112^{\prime}$ & $80^{\circ} 05.676^{\prime}$ \\
DC6* & NRC & 4.6 & $25^{\circ} 57.099^{\prime}$ & $80^{\circ} 06.534^{\prime}$ \\
DC7* & 16.8 & $25^{\circ} 57.530^{\prime}$ & $80^{\circ} 05.639^{\prime}$ \\
DC8* & 4.6 & $25^{\circ} 40.707^{\prime}$ & $80^{\circ} 07.111^{\prime}$ \\
\hline An & NRC & ${ }^{\circ}$ & & \\
\hline
\end{tabular}

An asterisk $\left({ }^{*}\right)$ next to a site represents sites that were not surveyed in 2012. $N R C=$ Nearshore Ridge Complex, MC = Martin County, PB = Palm Beach County, $B C=$ Broward County, $D C=$ Miami-Dade County.

significant $(p=0.094 ; p=0.031 ; p=0.100$, respectively). As benthic temperatures increased in the region, increases in coral bleaching and disease prevalence were also observed. Mean bleaching (bleached + partially bleached) prevalence changed significantly over the 5 years of monitoring $(p=0.005)$ and 2014 $(6.32 \pm 0.88 \%)$ and $2016(7.55 \pm 1.19 \%)$ were significantly greater than $2012(2.01 \pm 0.51 \%, p=0.047$ and $p=0.002$, respectively) (Table 2 and Supplementary Figure S1).

Not only was the maximum coral bleaching prevalence for the study period observed in 2016, but the same was also seen for disease prevalence. Mean disease prevalence in 2016 (3.29 $\pm 0.60 \%)$ more than doubled compared to 2015 $(1.49 \pm 0.35 \%)$ and was significantly greater than all previous years $(p<0.01)$ (Figure 3A). The increase in disease prevalence was primarily due to a region-wide outbreak of WS, which was over 2.6 times more prevalent in 2016 (2.48 $\pm 0.57 \%)$ compared to all other study years $(p<0.05)$ (Table 2$)$. Non-white syndrome diseases were prevalent in all study years, but the maximum prevalence for non-white syndrome never exceeded 1\% (Table 2). Additionally, non-white syndrome disease prevalence was driven by dark spot disease. While WS prevalence was only significantly greater in 2016, the outbreak was documented prior to 2016 (Figure 3B). White syndrome was first documented in the SECREMP demographic data at two sites in 2013 (BC4 and DC8). Over the next 3 years, WS was documented in at least one site in all four counties, and each year all habitats had at least one site with WS (Supplementary Table S2). Additionally, the number of sites impacted progressively increased from four sites in 2014 to eight sites in 2015 and 13 sites in 2016. Seven sites had significant increases in WS prevalence $(p<0.05)$ between 2012 and 2016 with the greatest increase and highest mean occurring at BC1 in $2016(14.39 \pm 2.95 \%)$ (Supplementary Table S2).

In addition to being geographically widespread, the WS outbreak appeared indiscriminate, affecting 11 of the 24 coral species recorded throughout the study period (Figure 4 and Supplementary Table S3). WS prevalence increased in terms of number of species affected as well as within species from 2013 to 2016, although no significant trends within species were found (Mann-Kendall, $p>0.05$ ). In 2013, only two species, Dichocoenia stokesii and Porites astreoides, were affected by WS. This increased to six species in 2014, nine in 2015, and seven in 2016. Over the four years in which WS was observed, species prevalence ranged from $0.17 \%$ for P. astreoides in 2015 to $25 \%$ for Eusmilia fastigiata in 2016 (Supplementary Table S3). Additionally, the highest prevalence per species was observed in 2015 and 2016. In 2015 , D. stokesii $(10.91 \%)$ and O. annularis complex $(8.33 \%)$ prevalence exceeded 5\%. Prevalence was even greater in 2016 with four species having prevalence > 10\%: E. fastigiata (25\%), Montastraea cavernosa (15.32\%), Solenastrea bournoni (13.16\%), and O. annularis complex (12.5\%).

\section{White Syndrome Outbreak Coincides With Coral Community Declines}

The wide geographical impact and the multiple host species susceptible to WS corresponded with changes to the coral communities of southeast Florida, which was evident by examination of community diversity. At the regional level, all three measures were significantly lower in 2016 (S: $4.92 \pm 0.19$, $\left.\mathrm{H}^{\prime}: 1.24 \pm 0.04, \mathrm{D}: 3.08 \pm 0.10\right)$ compared to all other years $(p<0.001)$ (Supplementary Figure S2). At the site level, significant changes were also observed for all three measures $(p<0.05)$, with one site that significantly increased, PB1 (S: $p<0.01$; $\mathrm{H}^{\prime}: p<0.05$; $\left.\mathrm{D}: p<0.001\right)$. $\mathrm{PB} 1$ is a nearshore ridge complex site in Palm Beach County that has been impacted by sand movement. PB1 was buried by sediment for several years, but has become more exposed since 2013. For species richness nine sites had significantly fewer species in 2016 compared to other years $(p<0.05)$. Significant decreases were also observed for Shannon's index and Inverse Simpson's index at ten and seven sites, respectively $(p<0.05)$ (Supplementary Table S4).

In an effort to determine whole colony mortality related changes at the population-level, coral density was analyzed. Prior to 2016, annual mean stony coral density throughout southeast Florida was slightly increasing. Mean density significantly $(p<0.001)$ decreased from $1.29 \pm 0.10$ colonies $/ \mathrm{m}^{2}$ in 2015 to $1.07 \pm 0.09$ colonies $/ \mathrm{m}^{2}$ in 2016 . Coral density in 2016 was also significantly lower than $2012\left(1.15 \pm 0.10\right.$ colonies $\left./ \mathrm{m}^{2}, p 0.01\right)$, $2013\left(1.21 \pm 0.09\right.$ colonies $\left./ \mathrm{m}^{2}, p<0.01\right)$, and $2014(1.26 \pm 0.10$ colonies $/ \mathrm{m}^{2}, p<0.001$ ) (Figure 5). For the 22 sites monitored, 18 sites had declines in coral density, six of which were significant $(p<0.05)$. The declines ranged from 10 to $52 \%$ and were not localized to one subregion or habitat, but were distributed between all habitats in Palm Beach, Broward, and Miami-Dade counties (Figure 6). 


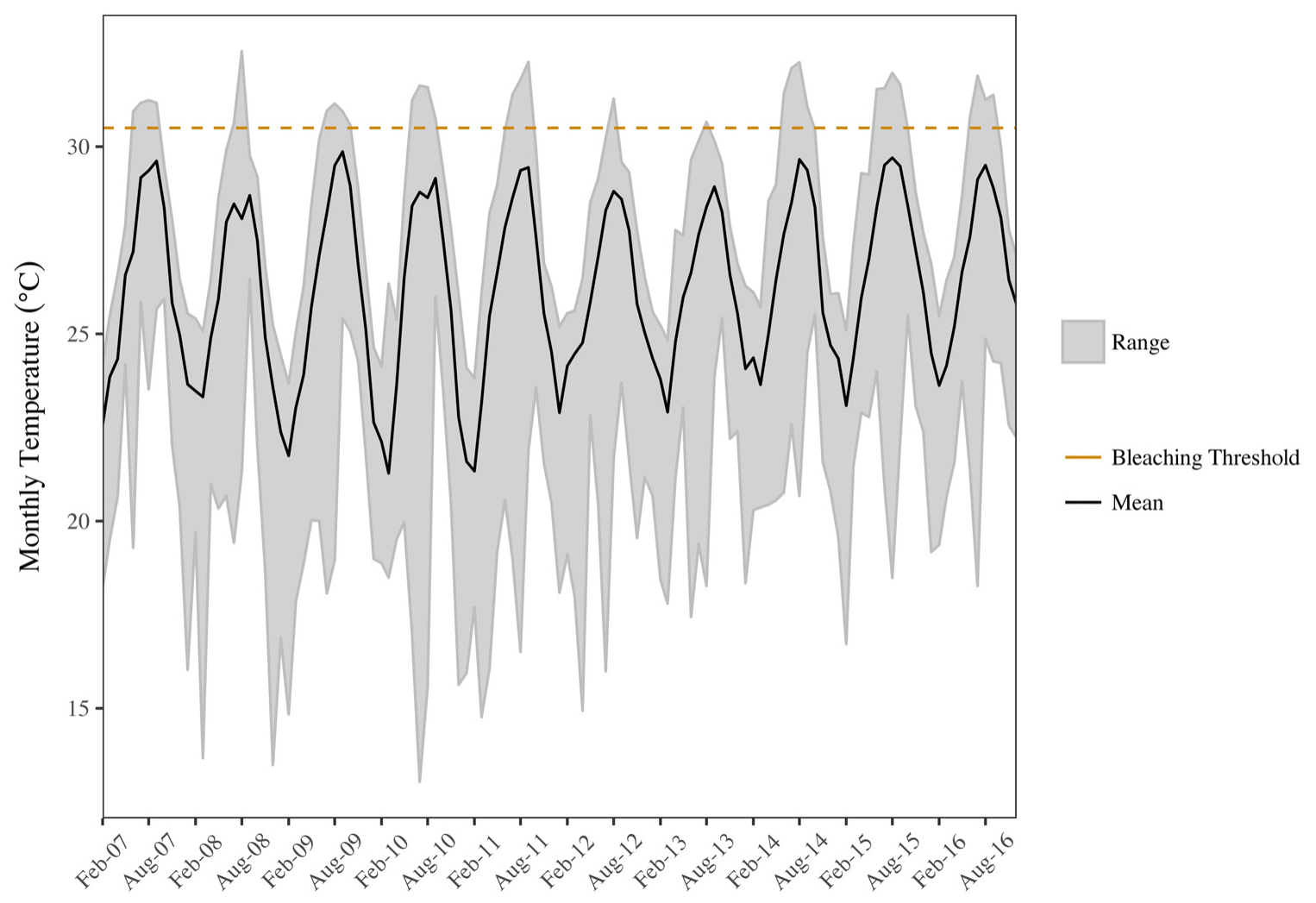

FIGURE 2 | Minimum, mean, and maximum monthly benthic temperatures for the SECREMP region. The black line indicates the mean monthly temperature, the gray ribbon is the range between the monthly minimum and maximum, and the dashed orange line indicates a documented bleaching threshold for the Florida Reef Tract $\left(30.5^{\circ} \mathrm{C}\right.$; Manzello et al., 2007).

TABLE 2 | Mean ( \pm SE) annual bleaching and disease prevalence.

\begin{tabular}{lcccc}
\hline Year & Bleaching (\%) & All diseases (\%) & $\begin{array}{c}\text { White } \\
\text { syndrome (\%) }\end{array}$ & $\begin{array}{c}\text { Non-white } \\
\text { syndrome (\%) }\end{array}$ \\
\hline 2012 & $2.01 \pm 0.51$ & $0.26 \pm 0.11$ & $0.00 \pm 0.00$ & $0.26 \pm 0.11$ \\
2013 & $4.39 \pm 1.27$ & $0.51 \pm 0.23$ & $0.08 \pm 0.05$ & $0.43 \pm 0.22$ \\
2014 & $6.32 \pm 0.88$ & $1.24 \pm 0.34$ & $0.82 \pm 0.32$ & $0.41 \pm 0.14$ \\
2015 & $5.19 \pm 0.80$ & $1.49 \pm 0.35$ & $0.95 \pm 0.30$ & $0.54 \pm 0.19$ \\
2016 & $7.55 \pm 1.19$ & $\mathbf{3 . 2 9} \pm \mathbf{0 . 6 0}$ & $\mathbf{2 . 4 8} \pm \mathbf{0 . 5 7}$ & $0.81 \pm 0.23$ \\
\hline
\end{tabular}

Percent bleaching included bleached and partially bleached colonies and all disease prevalence included all corals exhibiting signs of disease. Values in bold are significantly different from all other years.

Species-level density was analyzed for changes indicating whole colony mortality. Four species had densities in 2016 that were significantly lower than they had been in previous years $(p<0.05)$ and five additional species had their lowest densities, although not significant $(p>0.05)$. M. cavernosa, D. stokesii, and Meandrina meandrites, all species with elevated WS prevalence, had significant declines in density (Figure 5; $p<0.0001)$. Additionally, significant decreases in density were also observed for Siderastrea siderea $(p<0.0001)$ and Acropora cervicornis $(p<0.05)$. The $A$. cervicornis decline is not due to WS as this disease has not been documented affecting A. cervicornis. D. stokesii mean density declined by $90 \%$ from
$0.04 \pm 0.01$ colonies $/ \mathrm{m}^{2}$ (2014) to $0.004 \pm 0.002$ colonies $/ \mathrm{m}^{2}$ (2016). Meandrina meandrites density declined 95\% (2013: $0.06 \pm 0.01$ colonies $/ \mathrm{m}^{2}, 2016: 0.003 \pm 0.001$ colonies $/ \mathrm{m}^{2}$ ), while M. cavernosa (2012: $0.26 \pm 0.05$ colonies $/ \mathrm{m}^{2}, 2016: 0.13 \pm 0.02$ colonies $/ \mathrm{m}^{2}$ ) and S. siderea (2012: $0.25 \pm 0.02$ colonies $/ \mathrm{m}^{2}, 2016$ : $0.17 \pm 0.02$ colonies $/ \mathrm{m}^{2}$ ) declined 50 and $32 \%$, respectively. Additionally, when raw abundance values were examined they revealed D. stokesii counts decreased from 78 colonies in 2014 to 55 colonies in 2015, and eight colonies in 2016. M. meandrites showed similar declines from 118 colonies in 2014 to 85 colonies in 2015 and five colonies in 2016. While M. cavernosa abundance decreased as well, the major decline was not observed over multiple years, but occurred between 2015 (457 colonies) and 2016 (248 colonies), which is a $45 \%$ colony loss (Supplementary Table S3).

Changes in diversity and density are dependent on losses of whole colonies and corals exhibit colony partial mortality; therefore, LTA was used to examine population and species level changes related to partial mortality. Mean regional LTA in $2016\left(1.05 \pm 0.20 \mathrm{~m}^{2}\right)$ was significantly less than 2012 (1.68 $\left.\pm 0.42 \mathrm{~m}^{2}, p<0.0001\right), 2013\left(1.53 \pm 0.25 \mathrm{~m}^{2}, p=0.0001\right)$, $2014\left(1.59 \pm 0.28 \mathrm{~m}^{2}, p<0.0001\right)$, and $2015\left(1.62 \pm 0.31 \mathrm{~m}^{2}\right.$, $p<0.0001)$ (Figure 7A). At the site level, LTA decreased at 18 of the 22 sites between 2015 and 2016, 16 of which resulted in the lowest LTA values documented at the respective 

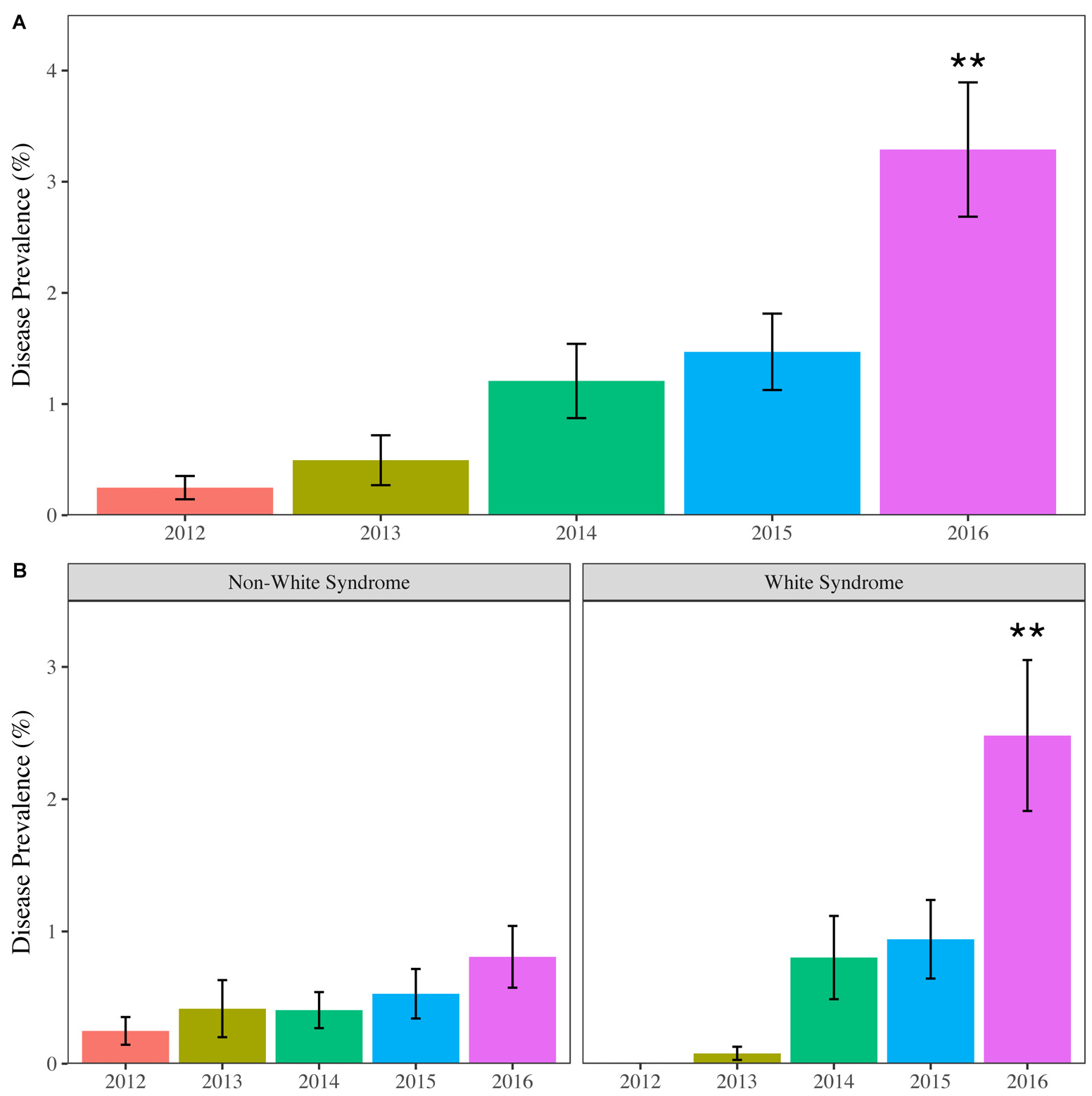

FIGURE 3 | Mean ( \pm SE) annual regional coral disease prevalence for (A) all diseases combined and (B) Non-white syndrome and white syndrome. Asterisks indicate years that are significantly different. ${ }^{* *} p<0.01$.

sites. Seven sites (PB2, PB4, and PB5; BC4 and BC5; DC1 and DC4) had significant decreases in LTA between 2012 and 2016 ( $p<0.05)$ (Supplementary Figure S3). All habitats within each county were represented by sites with decreased LTA (Supplementary Figure S3). Broward County 1, a site historically dominated by $M$. cavernosa, did not exhibit a significant change overall $(p=0.0564)$, but examination of pairwise annual changes revealed a significant decline in LTA between $2015\left(12.98 \pm 2.06 \mathrm{~m}^{2}\right)$ and $2016\left(8.06 \pm 1.57 \mathrm{~m}^{2}\right.$, $p=0.022)$. The significant decline observed at BC1 corresponded with a significant regional decrease in $M$. cavernosa mean LTA, resulting in $2016\left(0.66 \pm 0.23 \mathrm{~m}^{2}\right)$ being significantly lower than $2015\left(1.04 \pm 0.32 \mathrm{~m}^{2}, p=0.0015\right), 2014\left(1.01 \pm 0.30 \mathrm{~m}^{2}\right.$, $p=0.0017)$, and $2012\left(1.35 \pm 0.51 \mathrm{~m}^{2}, p<0.01\right)$. In addition to $M$. cavernosa, three other species exhibited significant changes in LTA, $P$. astreoides $(p<0.05)$, S. siderea $(p<0.05)$, and D. stokesii $(p<0.01)$ between 2012 and 2016. Siderastrea siderea and $D$. stokesii had significant declines, whereas $P$. astreoides LTA increased, with mean LTA in $2015\left(0.17 \pm 0.03 \mathrm{~m}^{2}\right.$, $p<0.05)$ and $2016\left(0.17 \pm 0.02 \mathrm{~m}^{2}, p<0.05\right)$ being significantly greater than $2012\left(0.11 \pm 0.02 \mathrm{~m}^{2}\right)$. For $S$. siderea mean LTA declined annually from $2013\left(0.09 \pm 0.02 \mathrm{~m}^{2}\right)$ to 2016 $\left(0.07 \pm 0.01 \mathrm{~m}^{2}\right)$, but only $2016(p<0.05)$ was significantly different from 2013. Similarly, D. stokesii mean LTA has steadily declined from 2013 to 2016, with $2015\left(0.03 \pm 0.02 \mathrm{~m}^{2}\right)$ and $2016\left(0.02 \pm 0.01 \mathrm{~m}^{2}\right)$ being significantly lower than 2013 


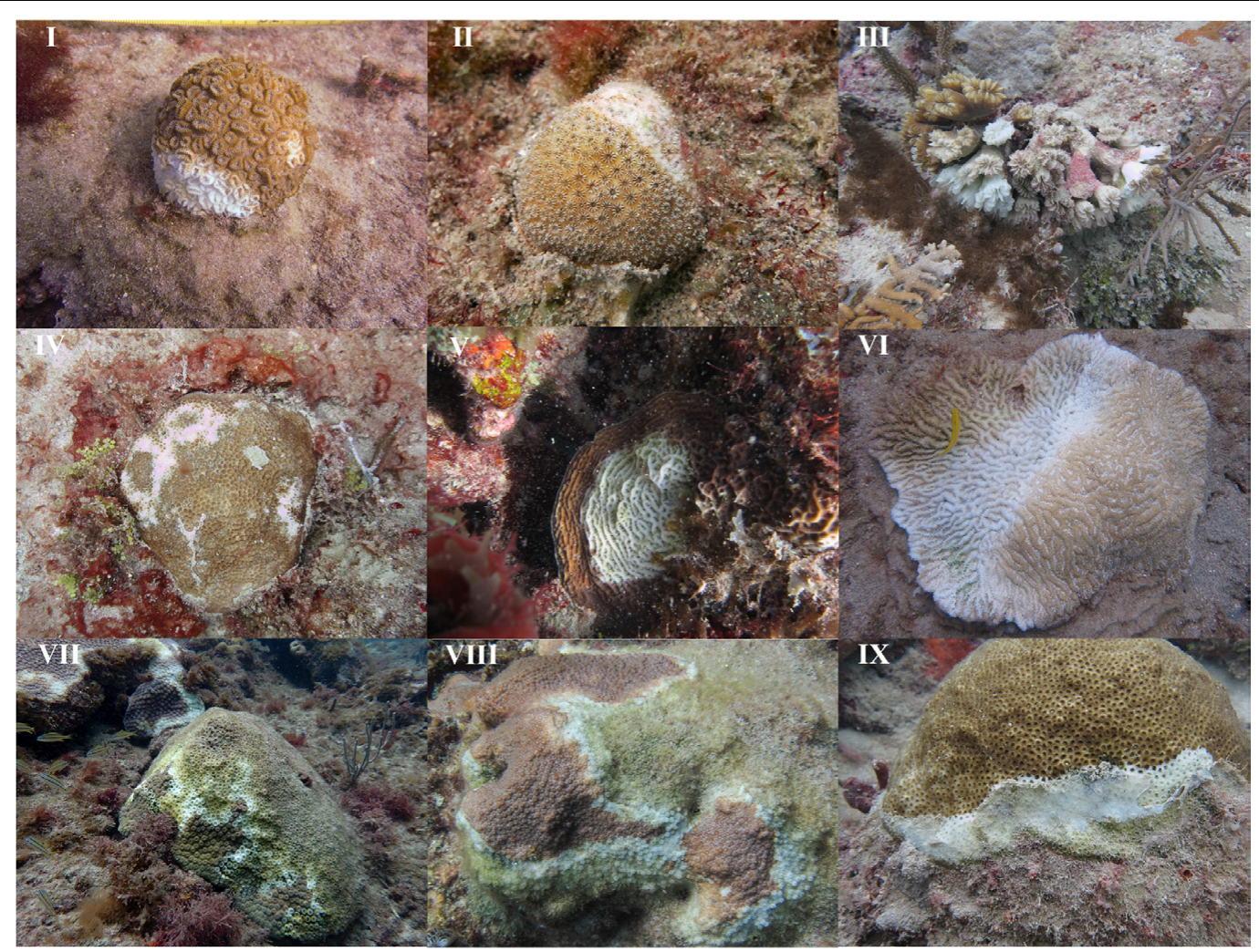

FIGURE 4 | Images of 9 of the 11 species affected by white syndrome during the outbreak. (I) Dichocoenia stokesii, (II) Stephanocoenia intersepta, (III) Eusmilia fastigiata, (IV) Siderastrea siderea, (V) Agaricia sp., (VI) Meandrina meandrites, (VII) Montastraea cavernosa, (VIII) Orbicella sp., (IX) Solenastrea bournoni.

$\left(0.06 \pm 0.02 \mathrm{~m}^{2}, p<0.05\right)$. M. meandrites also exhibited a drastic decline with $2016(0.004 \pm 0.000)$ being significantly lower than $2012(0.22 \pm 0.09, p<0.01), 2013(0.22 \pm 0.06, p<0.001)$, and $2014(0.19 \pm 0.05, p<0.001)$. This decline corresponded to the loss of all but five colonies in the region. In total, 15 species had declines in mean LTA between 2015 and 2016, leading to 10 total species having their lowest mean LTA in 2016 (Figure 7B). Additionally, of the 11 species exhibiting signs of WS during the study period, 10 had declines in LTA. Porites porites was the only species affected by WS that did not decline in LTA during the study period.

\section{DISCUSSION}

Our analysis of 5-years of SECREMP stony coral demographic data clearly shows that the Southeast Florida Reef Tract (SEFRT) was severely impacted by an ecosystem-altering disease outbreak that was unprecedented in terms of temporal scale $(3+$ years $)$, geographic extent (nearly $100 \mathrm{~km}$ between affected sites), number of species affected, and severity (colony mortality). We demonstrate that the outbreak began as early as summer 2014 and continued through 2016. During this period, the outbreak was a region-wide, multi-habitat event corresponding with significant declines in stony coral diversity, colony density, and LTA. Regionwide, 11 of 24-recorded species were documented with WS, four of which had significant regional declines in density and LTA. Increased disease prevalence coincided with the three warmest years on record (NOAA Coral Reef Watch, 2016), thus, thermal stress was very likely a major, but not sole contributor to the outbreak. Although not specifically addressed in this study, the cumulative impacts of multiple local stressors related to the close proximity of the SEFRT to a highly urbanized coast likely contributed to the unprecedented nature of this outbreak.

The disease outbreak documented here was a multi-year event impacting the SEFRT coral community. Disease prevalence in Miami-Dade and Broward counties in 2013 were similar to previously documented background levels (Muller and van Woesik, 2012; Ruiz-Moreno et al., 2012). In 2014, disease prevalence increased in West Palm Beach, Broward, and MiamiDade counties. Precht et al. (2016) reported the outbreak as white plague, near Virginia Key, Florida (Miami-Dade County) adjacent to major Port of Miami dredging activities in September 2014. Our data suggests the outbreak likely began earlier in 2014 as SECREMP sampling at all sites occurred prior to September 2014. Additionally, as early as 2014 the outbreak appeared to be more widespread than just in MiamiDade County as Precht et al. (2016) reported: two SECREMP sites (BC5 and BC6) in northern Broward County in 2014 had WS prevalence values of 4 and 13\%, respectively. White syndrome was also recorded in Palm Beach County in 2014, although at or below a previously documented background 


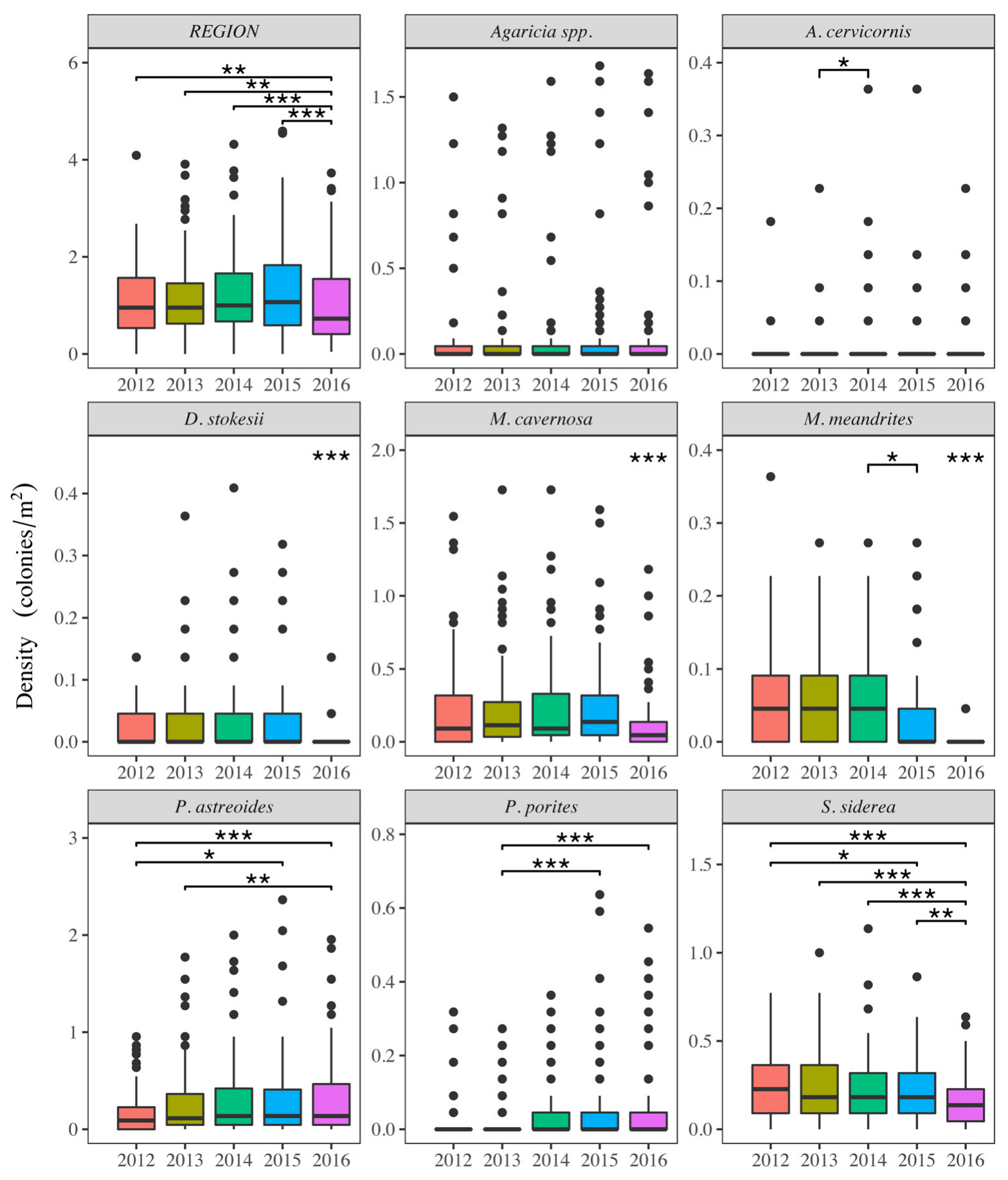

FIGURE 5 | Annual colony density for the region (top left) and coral species with significant changes from 2012 to 2016 ( $p<0.05)$. The middle bars of the boxplots represent the median values, the box length represents the interquartile range (IQR), the whiskers extend from the upper and lower IQR to the maximum and minimum values, and the dots indicate possible outliers. During this time period $P$. astreoides and $P$. porites had significant increases, Agaricia spp. had a significant overall change, but none of the pairwise comparisons were significant. All other species showed significant declines. Asterisks represent significant pairwise differences and the bars below the asterisks indicate the pairwise comparisons. ${ }^{*} p<0.05$; ${ }^{* *} p<0.01$; ${ }^{* * *} p<0.001$.

level (Muller and van Woesik, 2012; Ruiz-Moreno et al., 2012). White syndrome prevalence continued to increase reaching its maximum for the study period in 2016 and was documented in 13 of 22 sites distributed in multiple habitats ranging from
3 to $20 \mathrm{~m}$ depths in Palm Beach, Broward, and MiamiDade counties. While non-white syndrome diseases were documented throughout the study, their prevalence remained $<1 \%$ (Table 2). Additionally, dark spot disease was the 


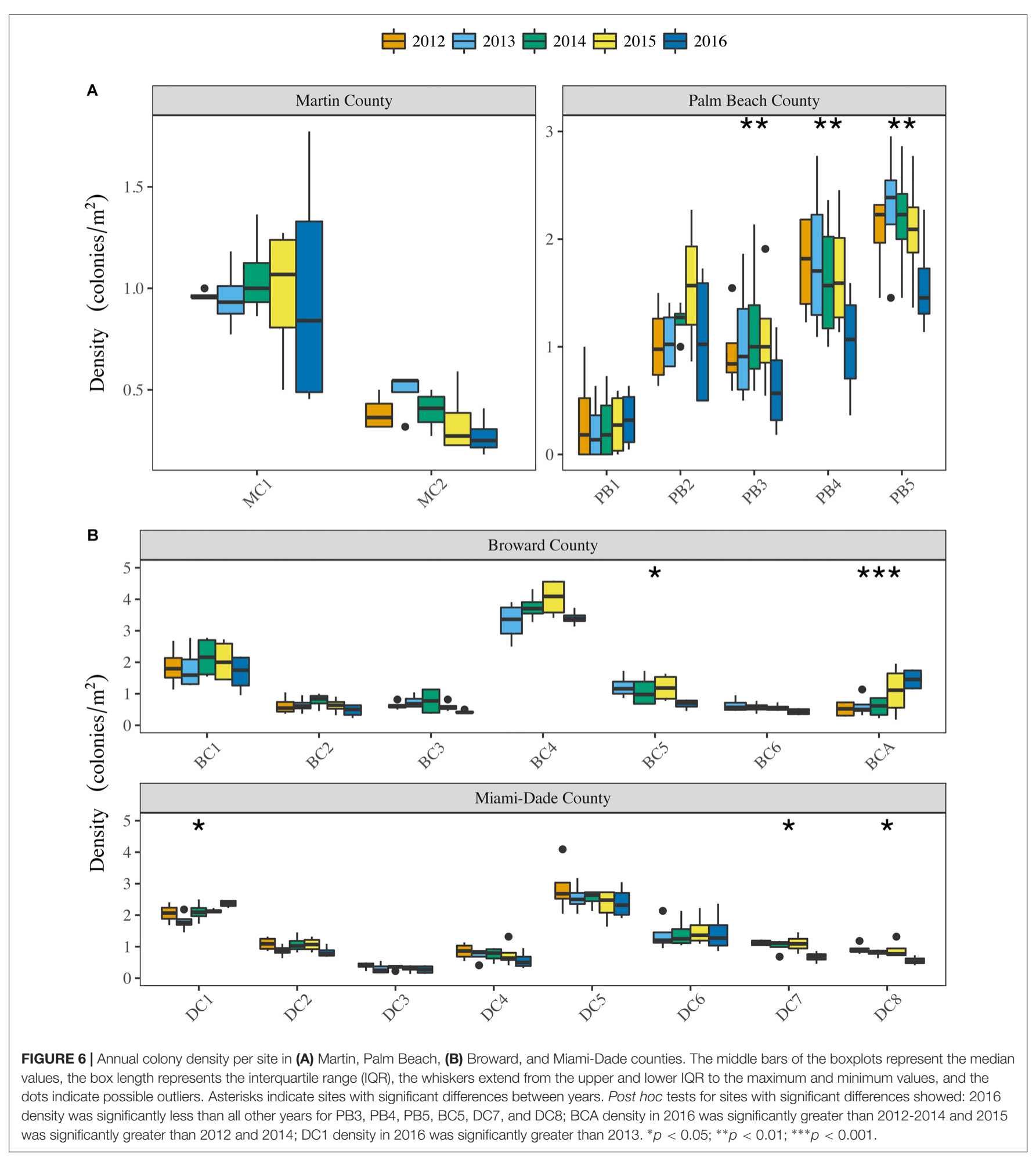

primary contributor to non-white syndrome diseases, which most often does not result in mortality (Borger, 2003, 2005). Our prevalence data showed the wide geographic extent and longevity of the outbreak even in light of the challenges of capturing this type of data during annual monitoring events. Our annual data most certainly underestimated the extremely high disease prevalence such as those reported by Precht et al. (2016).

Coinciding with the outbreak, significant declines in coral species diversity and colony density were observed, both of which have been suggested as indicators of reef resilience (Maynard et al., 2017; van Woesik, 2017). White syndrome 

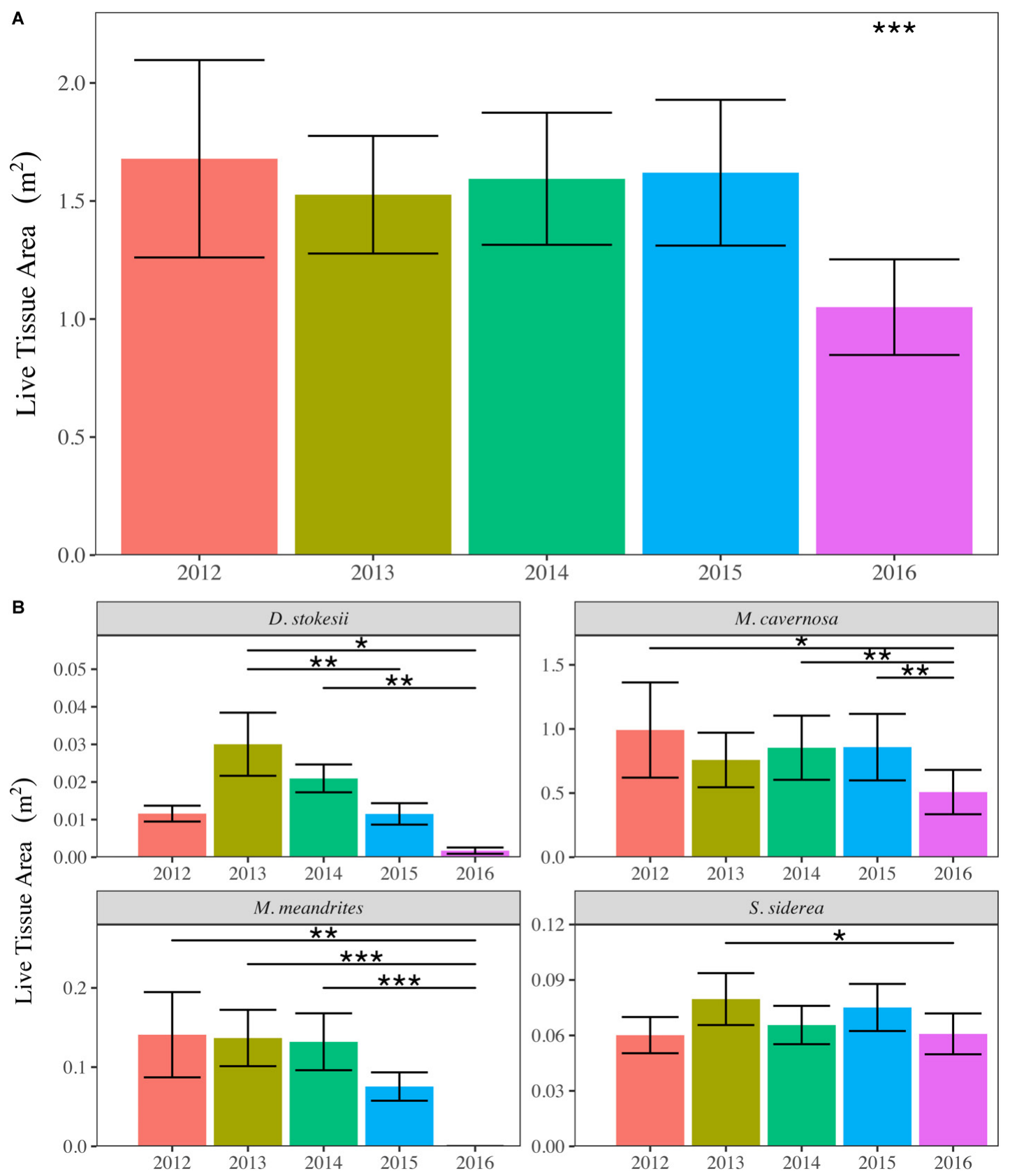

FIGURE 7 | Annual mean ( \pm SE) stony coral live tissue area (LTA) for the SECREMP (A) region and (B) coral species with significant declines due to white syndrome. Regional LTA in 2016 was significantly less than all other years. Asterisks indicated significant differences between years and the bars below the asterisks indicate the pairwise comparisons. ${ }^{*} p<0.05 ;{ }^{* *} p<0.01$; $^{* *} p<0.001$.

outbreak related declines in coral diversity and density are cause for concern for the already severely stressed SEFRT. Coral diversity declines have been associated with shifts in ecosystem function and stability, increased susceptibility to selective pressures, and reduced resilience and adaptability (van Woesik, 2002, 2017). Additionally, declines in diversity and density contribute to the loss of reef architecture, which can lead to decreased biodiversity of the reef system, specifically with respect to fish communities (Roberts et al., 2002;
Alvarez-Filip et al., 2009). The loss of architecture is becoming evident as reef building, complexity-contributing species like M. cavernosa, M. meandrina, and S. siderea exhibited significant declines. The declines in these occurred as increases in more "weedy" species like P. astreoides, P. porites, and Agaricia spp. (Figure 5) were also documented. These species typically grow as small, flat colonies resulting in reduced reef complexity (Knowlton, 2001; Precht and Miller, 2007; Green et al., 2008). 
Similar to reduced diversity and density, reductions in LTA can alter individual colony contributions to ecosystem function and reef habitat quality (Cote et al., 2005; Bruno and Selig, 2007). Regional LTA significantly decreased in 2016 (Figure 7A), particularly as a result of major losses in specific species affected by WS. Additionally when considering LTA as equivalent to cover, reduced LTA can affect a colony's reproductive potential, reducing the likelihood of recovery following disturbance events. Hartmann et al. (2017) showed high coral cover populations produced more larvae per square centimeter of tissue leading to higher larval outputs per square meter of reef. Based on this, reductions in LTA diminish the potential for larval production and output yielding decreased possibilities for successful sexual reproduction. Beyond the decline of LTA as a measure of benthic cover, decreased LTA is also indicative of reduced tissue per individual colony. Previously determined relationships between colony size and fecundity suggest that our observed decreases in LTA could lead to reductions in fecundity (Connell, 1973; Szmant-Froelich, 1985; Ward, 1995; Tsounis et al., 2006). As a result of the probable decreases in fecundity and reproductive potential of many of the remaining SEFRT corals, the likelihood of recovery is greatly reduced.

The 2014 to 2016 disease outbreak was arguably the most devastating disturbance event yet documented in the SEFRT, and has altered ecosystem function to a point where recovery is greatly challenged. Our data estimates that regionally as much as $30 \%$ of coral colony density and $60 \%$ of LTA was lost. Globally, ocean warming related coral bleaching events coupled with disease outbreaks are predicted to become more frequent and severe (Maynard et al., 2015). As thermal stress event frequency increases, time between events decreases, greatly limiting recovery potential, and this scenario is suggested to occur at even the most remote reefs (Hughes et al., 2018). The SEFRT is not remote. In addition to being a high-latitude system near the environmental threshold for significant coral reef growth, the SEFRT is offshore of a highly urbanized area driving increased nutrient loading from urban runoff and defining the ever-increasing need for marine construction projects (beach nourishment, port dredging, etc.) to support coastal development.

Global climate change related stress is challenging for local resource managers to address; however, with a greater understanding of the relative importance of local anthropogenic stressors contributing to increased coral disease prevalence, local management strategies can be developed to reduce diseaserelated impacts and facilitate recovery (Beeden et al., 2012). The irreplaceable economic and recreational benefits of the SEFRT are threatened because the system is under varied and chronic stress. Local resource management strategies need to include stronger regulations to reduce local drivers of stress such as development-related sedimentation (Pollock et al., 2014; Miller et al., 2016; Fourney and Figueiredo, 2017) and nutrient loading (Vega Thurber et al., 2013). Credible information is required to inform management, and SECREMP captured dramatic impacts to the SEFRT related to a major coral disease outbreak. Long-term monitoring provides annual status data on reef health and condition from which spatial and temporal changes to the system can be determined. Long-term monitoring will be required to document the success of management actions in response to this disease outbreak and further inform management decision-making. The SEFRT may be a harbinger for declines in other reef areas around the world subjected to similar cumulative global and local stresses. As population increases and coastal development intensifies, coral reef resiliency will depend upon our thorough understanding of the cumulative impacts local and global stressors driving declines and limiting recovery.

\section{DATA AVAILABILITY STATEMENT}

All data used in this manuscript are available from the Florida Fish and Wildlife Conservation Commission. Requests for data should be emailed to Corals@MyFWC.com and Francisco.Pagan@FloridaDep.gov.

\section{AUTHOR CONTRIBUTIONS}

CW, NH, and DG conducted the fieldwork and wrote and edited the manuscript. CW performed the statistical analysis.

\section{FUNDING}

This work was funded pursuant to Florida Department of Environmental Protection (FDEP) Grant Nos. RM085 and RM143 to the Florida Fish and Wildlife Conservation Commission (FWC) and then contracted to Nova Southeastern University. Though funded in part by a grant agreement from FDEP through National Oceanic and Atmospheric Administration (NOAA) Award Nos. NA13NOS4820015 and NA15NOS4820036 to FDEP, the views, statement, findings, conclusions, and recommendations expressed herein are those of the author(s) and do not necessarily reflect the views of the State of Florida or NOAA or any of their subagencies.

\section{ACKNOWLEDGMENTS}

We thank the numerous members of the NSU Coral Reef Restoration, Assessment and Monitoring Lab for their tireless efforts in the field and lab throughout the 14 years of SECREMP. We also thank our FRT monitoring partners in the Florida Fish and Wildlife Conservation Commission Coral Program, especially Rob Ruzicka, Mike Colella, Vanessa Brinkhuis, and Jeff Beal as well as the Florida Department of Environmental Protection Coral Reef Conservation Program, especially Joanna Walczak and Francisco Pagan.

\section{SUPPLEMENTARY MATERIAL}

The Supplementary Material for this article can be found online at: https://www.frontiersin.org/articles/10.3389/fmars.2018. 00323/full\#supplementary-material 


\section{REFERENCES}

Alvarez-Filip, L., Dulvy, N. K., Gill, J. A., Cote, I. M., and Watkinson, A. R. (2009). Flattening of Caribbean coral reefs: region-wide declines in architectural complexity. Proc. Biol. Sci. 276, 3019-3025. doi: 10.1098/rspb.2009.0339

Aronson, R. B., and Precht, W. F. (2001). White-band disease and the changing face of Caribbean coral reefs. Hydrobiologia 460, 25-38. doi: 10.1023/A: 1013103928980

Beeden, R., Maynard, J. A., Marshall, P. A., Heron, S. F., and Willis, B. L. (2012). A framework for responding to coral disease outbreaks that facilitates adaptive management. Environ. Manag. 49, 1-13. doi: 10.1007/s00267-011-9770-9779

Borger, J. L. (2003). Three scleractinian coral diseases in Dominica, West Indies: distribution, infection patterns and contribution to coral tissue mortality. Rev. Biol. Trop. 51(Suppl. 4), 25-38.

Borger, J. L. (2005). Dark spot syndrome: a scleractinian coral disease or a general stress response? Coral Reefs 24, 139-144. doi: 10.1007/s00338-004-0434-436

Bruno, J. F., Petes, L. E., Harvell, C. D., and Hettinger, A. (2003). Nutrient enrichment can increase the severity of coral diseases. Ecol. Lett. 6, 1056-1061. doi: 10.1046/J.1461-0248.2003.00544.X

Bruno, J. F., and Selig, E. R. (2007). Regional decline of coral cover in the Indo-Pacific: timing, extent, and subregional comparisons. PLoS One 2:e711. doi: 10.1371/journal.pone.0000711

Bruno, J. F., Selig, E. R., Casey, K. S., Page, C. A., Willis, B. L., Harvell, C. D., et al. (2007). Thermal stress and coral cover as drivers of coral disease outbreaks. PLoS Biol. 5:e124. doi: 10.1371/journal.pbio.0050124

Carlton, R. G., and Richardson, L. L. (1995). Oxygen and sulfide dynamics in a horizontally migrating cyanobacterial mat: black band disease of corals. FEMS Microbiol. Ecol. 18, 155-162. doi: 10.1111/j.1574-6941.1995.tb00173.x

Connell, J. H. (1973). Population ecology of reef-building corals. Biol. Geol. Coral Reefs 2, 205-245. doi: 10.1016/B978-0-12-395526-5.50015-8

Cote, I. M., Gill, J. A., Gardner, T. A., and Watkinson, A. R. (2005). Measuring coral reef decline through meta-analyses. Philos. Trans. R. Soc. Lond. B Biol. Sci. 360, 385-395. doi: 10.1098/rstb.2004.1591

Croquer, A., Pauls, S. M., and Zubillaga, A. L. (2003). White plague disease outbreak in a coral reef at Los Roques National Park, Venezuela. Rev. Biol. Trop. 51, 39-45.

Croquer, A., and Weil, E. (2009). Changes in Caribbean coral disease prevalence after the 2005 bleaching event. Dis. Aquat. Organ. 87, 33-43. doi: 10.3354/ dao02164

Dustan, P. (1977). Vitality of reef coral populations off Key Largo, Florida: recruitment and mortality. Environ. Geol. 2, 51-58. doi: 10.1007/BF02430665

Dustan, P., and Halas, J. C. (1987). Changes in the reef-coral community of Carysfort reef, Key Largo, Florida: 1974 to 1982. Coral Reefs 6, 91-106. doi: $10.1007 / \mathrm{bf} 00301378$

Eakin, C., Liu, G., Gomez, A., De La Cour, J., Heron, S., Skirving, W., et al. (2016). Global coral bleaching 2014-2017: status and an appeal for observations. Reef Encount. 31, 20-26.

Edmunds, P. J. (1991). Extent and effect of black band disease on a Caribbean reef. Coral Reefs 10, 161-165. doi: 10.1007/bf00572175

Fourney, F., and Figueiredo, J. (2017). Additive negative effects of anthropogenic sedimentation and warming on the survival of coral recruits. Sci. Rep. 7:12380. doi: 10.1038/s41598-017-12607-w

Gilliam, D. S., Walton, C. J., Hayes, N. K., Ruzicka, R., Colella, M. A., and Brinkhuis, V. (2017). Southeast Florida Coral Reef Evaluation and Monitoring Project 2016 Year 14 Final Report. Florida DEP Report NO RM085. Miami Beach, FL, 43.

Gladfelter, W. B. (1982). White-band disease in Acropora palmata: implications for the structure and growth of shallow reefs. Bull. Mar. Sci. 32, 639-643.

Green, D. H., Edmunds, P. J., and Carpenter, R. C. (2008). Increasing relative abundance of Porites astreoides on Caribbean reefs mediated by an overall decline in coral cover. Mar. Ecol. Prog. Ser. 359, 1-10. doi: 10.3354/meps 07454

Hartmann, A. C., Marhaver, K. L., and Vermeij, M. J. A. (2017). Corals in healthy populations produce more larvae per unit cover. Conserv. Lett. 11:e12410. doi: $10.1111 /$ conl.12410

Harvell, C. D., Mitchell, C. E., Ward, J. R., Altizer, S., Dobson, A. P., Ostfeld, R. S., et al. (2002). Climate warming and disease risks for terrestrial and marine biota. Science 296, 2158-2162. doi: 10.1126/science.1063699
Hothorn, T., Bretz, F., and Westfall, P. (2008). Simultaneous inference in general parametric models. Biom. J. 50, 346-363. doi: 10.1002/bimj.200810425

Hughes, T. P., Kerry, J. T., Baird, A. H., Connolly, S. R., Dietzel, A., Eakin, C. M., et al. (2018). Global warming transforms coral reef assemblages. Nature 556, 492-496. doi: 10.1038/s41586-018-0041-42

Klamkin, M. S. (1971). Elementary approximations to the area of N-dimensional ellipsoids. Am. Math. Mon. 78, 280-283. doi: 10.1080/00029890.1971.11992746

Klamkin, M. S. (1976). Corrections to "elementary approximations to the area of N-dimensional ellipsoids”. Am. Math. Mon. 83:478.

Knowlton, N. (2001). The future of coral reefs. Proc. Natl. Acad. Sci. U.S.A. 98, 5419-5425. doi: 10.1073/pnas.091092998

Kuta, K. G., and Richardson, L. L. (1996). Abundance and distribution of black band disease on coral reefs in the northern Florida keys. Coral Reefs 15, 219-223. doi: 10.1007/BF01787455

Lamb, J. B., Willis, B. L., Fiorenza, E. A., Couch, C. S., Howard, R., Rader, D. N., et al. (2018). Plastic waste associated with disease on coral reefs. Science 359, 460-462. doi: 10.1126/science.aar3320

Manzello, D. P. (2015). Rapid recent warming of coral reefs in the Florida keys. Sci. Rep. 5:16762. doi: 10.1038/srep 16762

Manzello, D. P., Berkelmans, R., and Hendee, J. C. (2007). Coral bleaching indices and thresholds for the Florida Reef Tract, Bahamas, and St. Croix, US Virgin Islands. Mar. Pollut. Bull. 54, 1923-1931. doi: 10.1016/j.marpolbul.2007. 08.009

Maynard, J., Byrne, J., Kerrigan, K., Tracey, D., Bohnsack, K., Pagan, F., et al. (2017). Coral Reef Resilience to Climate Change in the Florida Reef Tract. Miami, FL: Florida Department of Environmental Protection.

Maynard, J., van Hooidonk, R., Eakin, C. M., Puotinen, M., Garren, M., Williams, G., et al. (2015). Projections of climate conditions that increase coral disease susceptibility and pathogen abundance and virulence. Nat. Clim. Chan. 5, 688-694. doi: 10.1038/nclimate2625

McLeod, A. I. (2011). Kendall: Kendall rank Correlation and Mann-Kendall Trend Test. $R$ package version 2.2. Available at: https://CRAN.R-project.org/package= Kendall

Miller, J., Muller, E., Rogers, C., Waara, R., Atkinson, A., Whelan, K. R. T., et al. (2009). Coral disease following massive bleaching in 2005 causes $60 \%$ decline in coral cover on reefs in the US Virgin Islands. Coral Reefs 28, 925-937. doi: 10.1007/s00338-009-0531-537

Miller, M. W., Karazsia, J., Groves, C. E., Griffin, S., Moore, T., Wilber, P., et al. (2016). Detecting sedimentation impacts to coral reefs resulting from dredging the Port of Miami, Florida USA. PeerJ 4:e2711. doi: $10.7717 /$ peerj. 2711

Muller, E. M., and van Woesik, R. (2012). Caribbean coral diseases: primary transmission or secondary infection? Glob. Chan. Biol. 18, 3529-3535. doi: $10.1111 /$ gcb.12019

NOAA Coral Reef Watch (2016). 2016 Annual Summaries of Thermal Conditions Related to Coral Bleaching for the U.S. Coral Reef Jurisdictions. Washington, DC: US Department of Commerce.

Pinheiro, J., Bates, D., DebRoy, S., Sarkar, D., and R Core Team (2017). nlme: Linear and Nonlinear Mixed Effects Models. R package version 3.1-131. Available at: https://CRAN.R-project.org/package=nlme

Pollock, F. J., Lamb, J. B., Field, S. N., Heron, S. F., Schaffelke, B., Shedrawi, G., et al. (2014). Sediment and turbidity associated with offshore dredging increase coral disease prevalence on nearby reefs. PLoS One 9:e102498. doi: 10.1371/journal. pone.0102498

Pollock, F. J., Morris, P. J., Willis, B. L., and Bourne, D. G. (2011). The urgent need for robust coral disease diagnostics. PLoS Pathog. 7:e1002183. doi: 10.1371/ journal.ppat.1002183

Pollock, F. J., Wada, N., Torda, G., Willis, B. L., and Bourne, D. G. (2017). White syndrome-affected corals have a distinct microbiome at disease lesion fronts. Appl. Environ. Microbiol. 83:e02799-16. doi: 10.1128/AEM.02799-16

Precht, W. F., Gintert, B. E., Robbart, M. L., Fura, R., and van Woesik, R. (2016). Unprecedented disease-related coral mortality in Southeastern Florida. Sci. Rep. 6:31374. doi: 10.1038/srep31374

Precht, W. F., and Miller, S. L. (2007). "Ecological shifts along the Florida reef tract: the past as a key to the future," in Geological Approaches to Coral Reef Ecology, ed. R. B. Aronson (Berlin: Springer), 237-312.

R Core Team (2017). R: A Language and Environment for Statistical Computing. Vienna: R Foundation for Statistical Computing. 
Randall, C. J., and van Woesik, R. (2015). Contemporary white-band disease in Caribbean corals driven by climate change. Nat. Clim. Chan. 5, 375-379. doi: 10.1038 /nclimate 2530

Richardson, L. L., Goldberg, W. M., Carlton, R. G., and Halas, J. C. (1998a). Coral disease outbreak in the Florida Keys: plague type II. Rev. Biol. Trop. 46, 187-198.

Richardson, L. L., Goldberg, W. M., Kuta, K. G., Aronson, R. B., Smith, G. W., Ritchie, K. B., et al. (1998b). Florida's mystery coral-killer identified. Nature 392, 557-558. doi: 10.1038/33302

Richardson, L. L., and Voss, J. D. (2005). Changes in a coral population on reefs of the northern Florida Keys following a coral disease epizootic. Mar. Ecol. Prog. Ser. 297, 147-156. doi: 10.3354/meps297147

Roberts, C. M., McClean, C. J., Veron, J. E. N., Hawkins, J. P., Allen, G. R., McAllister, D. E., et al. (2002). Marine biodiversity hotspots and conservation priorities for tropical reefs. Science 295, 1280-1284. doi: 10.1126/science. 1067728

Ruiz-Moreno, D., Willis, B. L., Page, A. C., Weil, E., Croquer, A., Vargas-Angel, B., et al. (2012). Global coral disease prevalence associated with sea temperature anomalies and local factors. Dis. Aquat. Organ. 100, 249-261. doi: 10.3354/ dao02488

Rutzler, K., Santavy, D. L., and Antonius, A. (1983). The black band disease of atlantic reef corals. Mar. Ecol. 4, 329-358. doi: 10.1111/j.1439-0485.1983. tb00118.x

Sutherland, K. P., and Ritchie, K. (2004). "White pox disease of the Caribbean Elkhorn coral Acropora palmata," in Coral Health and Disease, eds E. Rosenberg and Y. Loya (Berlin: Springer).

Szmant-Froelich, A. (1985). "The effect of colony size on the reproductive ability of the Caribbean coral Montastrea annularis (Ellis and Solander)," in Proceedings of the 5th International Coral Reef Symposium, Tahiti, 295-300.

Tsounis, G., Rossi, S., Aranguren, M., Gili, J.-M., and Arntz, W. (2006). Effects of spatial variability and colony size on the reproductive output and gonadal development cycle of the Mediterranean red coral (Corallium rubrum L.). Mar. Biol. 148, 513-527. doi: 10.1007/s00227-005-0100-108

van Woesik, R. (2002). Processes regulating coral communities. Comments Theor. Biol. 7, 201-214. doi: 10.1080/08948550214054

van Woesik, R. (2017). Contemporary coral bleaching: why diversity matters. Biodiversity 18, 16-18. doi: 10.1080/14888386.2017.1307142 van Woesik, R., and McCaffrey, K. R. (2017). Repeated thermal stress, shading, and directional selection in the Florida reef tract. Front. Mar. Sci. 4:182. doi: $10.3389 /$ fmars.2017.00182

Vega Thurber, R. L., Burkepile, D. E., Fuchs, C., Shantz, A. A., McMinds, R., and Zaneveld, J. R. (2013). Chronic nutrient enrichment increases prevalence and severity of coral disease and bleaching. Glob. Chang. Biol. 20, 544-554. doi: $10.1111 /$ gcb. 12450

Walker, B. K. (2012). Spatial analyses of benthic habitats to define coral reef ecosystem regions and potential biogeographic boundaries along a latitudinal gradient. PLoS One 7:e30466. doi: 10.1371/journal.pone.0030466

Ward, S. (1995). The effect of damage on the growth, reproduction and storage of lipids in the scleractinian coral Pocillopora damicornis (Linnaeus). J. Exp. Mar. Biol. Ecol. 187, 193-206. doi: 10.1016/0022-0981(94)00180-L

Weil, E. (2004). "Coral reef diseases in the wider Caribbean," in Coral Health and Disease, eds E. Rosenberg and Y. Loya (Berlin: Springer), 35-68. doi: 10.1007/ 978-3-662-06414-6_2

Weil, E., and Croquer, A. (2009). Spatial variability in distribution and prevalence of Caribbean scleractinian coral and octocoral diseases. I. Community-level analysis. Dis. Aquat. Organ. 83, 195-208. doi: 10.3354/dao02011

Wickham, H. (2009). ggplot2: Elegant Graphics for Data Analysis. New York, NY: Springer-Verlag. doi: 10.1007/978-0-387-98141-3

Williams, D. E., and Miller, M. W. (2005). Coral disease outbreak: pattern, prevalence and transmission in Acropora cervicornis. Mar. Ecol. Prog. Ser. 301, 119-128. doi: 10.3354/meps301119

Conflict of Interest Statement: The authors declare that the research was conducted in the absence of any commercial or financial relationships that could be construed as a potential conflict of interest.

Copyright (c) 2018 Walton, Hayes and Gilliam. This is an open-access article distributed under the terms of the Creative Commons Attribution License (CC BY). The use, distribution or reproduction in other forums is permitted, provided the original author(s) and the copyright owner(s) are credited and that the original publication in this journal is cited, in accordance with accepted academic practice. No use, distribution or reproduction is permitted which does not comply with these terms. 